\title{
Landowners' Perceptions towards the Success of Land Title Registration in Sri Lanka
}

\author{
Wickramaarachchi, N.C. ${ }^{1 *}$, Sewwandi, S $^{1}$, Thilini, K. A. M. ${ }^{1}$ \\ ${ }^{1}$ Department of Estate Management and Valuation,University of Sri Jayewardenepura, SriLanka.
}

\begin{abstract}
Recording information on land is a crucial factor for a country to maintain its wealth. Among different registration methods, the title registration system has been identified as the most acceptable, efficient, widely used,and secured system in the world. Sri Lanka introduced the title registration system in 1998 in selected areas of the country, but it is still less popular and shows low progress. Hence, there is a question on the success of the program . Thus, the objective of this study is to identify the factors that affect towards the slow progress and the disfavour in land title registration system in Sri Lanka. The perceptions of the landowners' who dealt with the new system were surveyed through a questionnaire prepared on pre-identified criteria. The results revealed that, the factors that were unfavourable and demote the success of the land title registration were related to the awareness, the trust, the trustworthiness and the access to information. Hence, it can be concluded that the landowners possess little knowledge onthe benefits of the program and felt uncertainty about the system. The policies should be formulated to improve the efficiency of the program by enhancing the awareness of the landowners to strengthen the trustfulness of the title registration process in Sri Lanka.
\end{abstract}

Keywords:Land administration, Land information, Property rights

\section{Introduction}

The history of land information recording in Sri Lanka dates back to the era of ancient Kings, during which different land registration systems existed in the country. In ancient Sri Lanka, the king was the sole custodian of the land, i.e the exclusive rights and the ownership of the land. The tenure of the land was given out to diffrent parties either to settle a payment or in return of a service.

The land was given by way of grants called sannasa (a grant of land usually engraved on a copper plate) and registered in a landroll - Lekammiti (a document written on 'ola leaf' which gave ownership information) with the intention that dues and services could be regularly executed (Pieris, 1989). The sannasa and the lekammiti were the methods the land information was recorded, using a copper plate and the ola leaf.
However, from 1505, Sri Lanka was influenced by the administrative procedures of the Portuguese, the Dutch, and the British respectively. The British introduced the deed registration system in 1863. This is the beginning of documentation of land title information officially on a paper. This system is still implemented to record information related to the transactions of land. However, having identified the deficiencies in the deed registration system. in 1998 the Government of Sri Lanka enacted the Registration of Title Act with all provisions to minimize the problems of the deed registration system.

Initially, this program was funded by the World Bank, and eventually, it was implemented by the Ministry of Lands and Land Development under the 'Land Titling and Related Services Project'. Since then, the country's land information base is

\footnotetext{
$1 *$ Corresponding Author:

(D) https://orcid.org/0000-0002-8206-1514

e-mail address: nishani@s.jp.ac.lk, sashimap94@gmail.com, mallkathilini@ gmail.com

DOI: http://doi.org/10.4038/bhumi.v8i1.74
} 
currently transiting from a 'deed registration system' to a 'title registration system'. However, the progress shows the targets are yet far more ahead to achieve indicating the slower progress than expected (Bimsaviya, 2009).

There are newly introduced regulations and a legal framework based on the concept of title registration. Therefore, it is necessary to promote awareness among the general public about the advantages of the new system of land registration. Attributes of good practices of land registration includes simple design of registration processes, minimum cost of operations, appropriateness of the technology, higher affordability by the user, higher operational efficiency, transparent operations, higher satisfaction of landowners and other stakeholders, equity and fairness in adjudication, certainty in outcomes, highly committed executing agency, and political support (AusAID, 2001).

The success of a land registration project depends on certain factors. Among them, 'acceptability' is one of the most important factor. According to Ayala \& Elder (2021), acceptability refers to how well an intervention will be received by the target population and the extent to which the new intervention meets the needs of the target population and organizational setting. In the implementation of a public project, its acceptability by the citizens of the country is important. Otherwise, the probability is high for it to be a failiure.

There are several factors that determine the acceptability of the land titling system. Acceptability will be high if there are economic, social, cultural, and environmental benefits (Rubasinghe, 2010). Further, the degree to which the landowner accepts the land registration process depends on his/her awareness, perception, attitude, trustworthiness, participation in the land registration process, and accessibility to information (Zevenbergen, 2004; 2006; Mitchell et al. 2008).
The study, reported herein aimed to identify the factors that denoted the success of the ongoing land title registration system in Sri Lanka and how far this system was accepted and responded by the public, through the perceptions of landowners. By assessing the factors such as awareness and participation, trust and trustworthiness, access to land information system and attitudes about the acceptability and the success of the land titling system in Sri Lanka can be inferred.

\section{Literature Review 2.1 Land Administration}

The objective of the governments of all around the world is to achieve the highest and best use of the lands under their jurisdictions. In such a scenario land administration accompanies several objectives. Nichols (1993) has explained certain objectives of land administration. It might include the development of efficient systems;

- To allocate rights to these resources,

- To provide security for private investments, and to prevent and resolve disputes.

Land administration is not a single activity, but it can be identified as a process. According to Burns et al. (2006) land administration is the process of determining, recording, and publishing information about land tenure, value, and use of land when realizing land management policies. Further, it is said that land administration is a system implemented by the state to record and manage the land rights. Land administration system includes the following major components:

- management of public land,

- recording and registration of the private rights in land,

- recording, registration, and

- publicizing of the awards or transferences of those rights in the land through, for example, sale, gift, encumbrance, subdivision, amalgamation and so on,

- management of the fiscal aspects related to rights in land together with land tax, historical sales data, 
- valuation for a range of purposes, the assessment of fees and taxes, compensation for state acquisition of private rights of the land and so forth, and

- control of the use of land, including land use zoning and support for the development application/ approval process

(Burns et al., 2006).

It is also defined that a land administration system comprises textual records that define rights and/or information and spatial records that define the extent to which these rights and/or information apply.

In any country, land administration is an extensive process and there are many complexities coupled with legal and administrative frameworks. According to Dale \& McLaughlin (1988), the process of land administration is very wide and includes the regulation of land and property development, the use and preservation of the land, gathering of revenues from the land through sales, leasing, and taxation, determining the conflicts concerning the ownership and use of the land.

In summary, the land administration focuses on the management of the land tenure system, monitoring the system, and enforcing many of the laws and regulations. To achieve these targets, land registration is also an important mechanism. Most of the land administration programs consist of land titling, land registration, or cadastral reform components.

\subsection{Land Registration System}

The following sections describe the historical background of land registration systems. Land registration is an essential requirement for a country in terms of implementing land administration.

According to Zevenbergen (2002), land registration systems are different among countries. It is not easy to function land registration system smoothly in a country, because many countries are experiencing different land tenuer issues. Therefore, it is important to improve the land tenure security as well.

Improving the security of tenure will facilitate and encourage investment on lands (Lengoiboni et al., 2018). A proper land registration system identifies land rights, and accordingly, the market value of the land. The term "pro-poor land recordation" denotes the advantages of land rights recording that seek out to address the needs of the poor, because it has been accepted that poor and marginalized groups have been neglected or negatively impacted by land rights documentation efforts in the past (UN-Habitat, 2007; Lengoiboni et al., 2019). Implementing a registration system enables providing accurate and productive land information that is very much important and necessary to the state.

According to Thontteh \& Omirin (2015), a land registration system is commonly defined as a system that deals with matters related to ownership, possession, or other rights in land. Such components can be recorded to provide evidence of title, while facilitating transactions and preventing unlawful disposal. In contrast, according to Griffith-Charles (2004), an appropriate definition for land registration is the process of initially recording legally valid rights to land. Land registration is one of the activities that comes under the process of land administration or land tenure security. There are three aspects of land registration systems considered in different countries. They are: (a) Private conveyancing; (b) Registration of deeds; and (c) Registration of titles.

In private conveyancing, a land transaction is handled in a very primitive and private level with no documents passed between the seller and the buyer. This is more of a verbal transaction that takes place between the buyer and the seller. Still, on some occasions, documents are handled. The state does not participate in the transaction and the documents never get to the public and registered. Instead, they are stored either by the landowners or with a notary. According to Dale \& McLaughlin (1999), this system does not provide any information to the 
state. Hence, it leads to high risk of fraud. Therefore, that registration system is considered as an inefficient and insecure system. Though private conveyance is not efficient, it is still implemented in some Latin American countries and African countries.

According to Henssen (1995), a deed registration is to register a transaction. It is a document that designates an insulated transaction. Further, this deed is an evidence of a particular transaction took place. Albeit, it is in principle not in itself to proof the legal rights of the involved parties. Consequently, it is not confirmation of its validity.

Thus, before any transaction to be safely effectuated, the supposed owner must suggest his ownership back to a good root of title. Many countries around the world implement the deed registration system (Perera, 2010). According to Ministry of Lands and Land Development, Sri Lanka, the deed registration system operates with three basic ordinances such as: (a) Registration of Document Ordinance of 1927, (b) Prevention of Fraud Ordinance of 1980, and (c) Notaries Ordinance.

Comparing the private conveyance with deed registration system, it is certain that relatively there are limitations in private conveyancing than in the deed registration system. According to BimSaviya (2009), there are certain deficiencies in the deed registration system, which can be stated as follows:

- Registration of a document prepared on land transaction (Deed) does not establish the absolute ownership or the title to the land.

- There is no clarity in terms of understanding the deed registration system.

- Location of the land indicated in the deed cannot be identified physically on the ground. Most of the deeds either do not have survey plans attached or have no survey plans at all.
- In this process it is the document which legally registered but not the "title".

- Establishing the ownership of land and obtaining a conclusive title report is a pensive, complex, and a lengthy process.

To overcome those limitations, and to improve the land registration process, the title registration system has been introduced

\subsection{Title Registration System}

The title registration system is more secure than other land registration systems. A title registration method involves not only the transfer of registered rights, but the legal concern of that transaction. The right together with the name of the rightful claimant, and the object of that right with its limitations and responsibilities are also registered with this registration (Henssen, 1995). In a system of title registration, one can immediately detect the owner of a property. Further a variety of systems of title registration may also exist (Zevenbergen, 2002).

Land title registration contains detecting a parcel or lot of land and determining the person(s) (or organization) with an ownership interest (or title) in it. These information are then recorded in a land register (Dale \& Binns, 1995). The title registration includes not only the name of the owner, location, and boundaries of the land, but also encumbrances and usage restrictions attaching to the land (Heryani\& Grant, 2004). Therefore, Simpson (1976) and Zevenbergen (2002) mentioned that "registration of title acts as a warranty of title in the person registered as owner and bars adverse claims".

Nevertheless, Roth \& Haase (1998) have stated that the land titling projects, therefore, are not always applicable for promotion of sustainable development in developing countries since the positive effect on security of tenure is not always attained. 
As per De Soto (1989) the land title registration plays a central role in unearthing the potential wealth in developing countries (Ehwi, \& Asante, 2016). Considering land title registration in three South-East Asian countries i.e. Brunei, Malaysia, and Singapore, it can be stated that the system of land title registration has been well-established, dating back over many years to the colonial period (Jones, 2010).

\subsubsection{Title Registration System in Sri Lanka}

Sri Lanka initiated a pilot project and a dialogue on land titling with the donor community in 1996 (Rydbberg et al., 2013, Illanganthilaka \& Mahanamahewa, 2017). The title registration system was implemented in 1998 to overcome the challenges of the deed registration system and private conveyance by introducing the Registration of Title Act No 21 of 1998. This practice has been commenced in Diulapitiya, Gampola, and Balangoda as the first selected areas with Land Settlement Department and the Survey Department.

The initial project commensed as 'Land Titling and Related Services Project' with the assistance of the World Bank and was launched in 2002. Nevertheless, this project was unable to define and put in place the legal, regulatory, and institutional framework, that was essential to effectively establish the land titling program on a national scale. Further, the project was also failed to enable the efficient operation of a land administration system (World Bank, 2001; Zainudeen, 2016).

In 2007, the government expanded the title registration program under the BimSaviya project (BimSaviya, 2009, Rubasinghe, 2010). This program $(2007-2021)$ targeted to register titles for nearly 10 million land parcels in Sri Lanka, free of charge. This program involved the Land Settlement Department, the Land Commissioner General's Department, the Registrar General's Department, the Survey Department, and Divisional Survey Offices
(Zainudeen, 2016). BimSaviya program was not successfull due to inadequate budget, technical resources, human resources, and due to implementing in a limited area. These were the main factors affected the overall program (Rubasinghe, 2010).Further, staff being drawn from different departments, inter-organizational conflicts, lack of an established chain of command for decision making, and decentralized field offices also affected the timely registration of titles (Rubasinghe, 2010).

\subsection{Factors Affecting to Land Title Registration System}

Rubasinghe (2010), emphasized that for the success of any system there were factors that influence the stakeholder's attitude to accept the system. Mostly, such factors existed beyond the technological, organizational, and legal aspects of the system. They are related to, socio-economic and cultural factors, awareness and participation, transparency, land information system, access to information, cost, and efficiency. These are briefly discussed below:

\section{(a) Socio Economic and Cultural Factors}

The land relates to social responsibilities, ethical commitment or attitude to environmental sustainability and good husbandry. Most significantly, the public treats land and property relating to their cultural traditions and ways of ethical behaviour. The system of land tenure and land use varies according to cultural differences. Similarly, cultural norms and regulations related to land too vary among diffrent societies. . Accordingly, the indicators to measure the socio-economic factors include education, gender, age, occupation, monthly income, number of land parcels, the extent of the land, land use type, etc. (Enemark, 2008; Rubasinghe, 2010)

\section{(b)Awareness and Participation}

Awareness is another important factor that affects the positive responsiveness towards the title registration system. Introducing a 
land registration system should ensure thorough awareness of all parties involved in the process, including the landowners. Unawareness of the title registration may result in objections for the registration. The major activities of the registration system are; the proper introduction of the legal framework related to the rights and obligation of people in land registrations, the systematic and registration process and sequence of the transaction, services, etc. Community participation is a key role in the successful implementation of systematic land registration (Lor, 2004; Rubasinghe, 2010).

If people are in possession of a piece of land, they should participate in its registration. . However, depending on the rights of the land, the level of participation may vary. The users of a land can be identified as freeholders, leaseholders, and subleaseholders, etc. The indicators of of the level of awareness, include; the participation in awareness programs, increased knowledge about the benefits of land titling programs, and quality of the awareness programs.

\section{(c) Trust and Trustworthiness}

According to David \& Hackman (1999), trust can be described as a social cognition that an individual applies to anything the individual thinks of as a unitary actor. According to Tuladhar \& Molen (2003), the value perceived by the customers increases satisfaction and similarly trust is also contributing factor to satisfaction. The degree of trust is contribution of service guarantee and higher standard of conduct. The trustworthiness can be defined as combining on that the records are reliable and accurate, and on which they are acceptable to the stake holders. For the land registration system the main emergent property is trustworthiness. It is not attributed to one or a few elements, but it depends on the registration system as a whole (Zevenbergen, 2002b).

(d) Land Information System and Access to Information
A land information system is an important tool for legal, administrative, cost-effective, and profitable decision-making, and it is very important in the context of planning and development. A land information system involves two parts; (a) the database that spatially refers to land-related data, and; (b) dealings with technology for the systematic collection, updating, processing, and distribution of data. This includes data updates, data sharing, access to public, publicity of information and source of the information about land titling program, effectiveness of the booklet, information flow of the progression of steps, and information about the gazettal cadastral map.

\section{e)Attitudes and Perceptions}

According to Enemark (2008), an attitude represents an individual's degree of liking or disliking of the system and it is generally the positive or negative views of a system. Simply, attitude is a state of mind or a feeling. Attitude is the preference of an individual towards or away from things or events (Becuro, 2010). The perception of land titling is measured as the representation of what is perceived or knowledge gained by perceiving about the program.

\section{Methodology}

The reserach adopted the case study method and itfocused on analyzing the perceptions of landowners' towards the successfulness of land title registration in Sri Lanka. The residents who had faced the titling program were the respondents of this study. The approach is mainly, quantitative and the following sections explain the study area, sample, data, data collection methods, and the approach to the analyse the data.

\subsection{The Study Area}

In Gampaha District, "BimSaviya" project is presently implemented in Minuwangoda, Attanagalla, Katana, Negombo, Wattala, JaEla, Gampaha, Mahara, Biyagama, Dompe, and Kelaniya Divisional Secretary Divisions. The study focussed to the 
recently BimSaviya project introduced areas in Gampaha District. Accordingly, Aththanagalla Pradeshiya Sabha area was selected for investigations. Attanagalla Pradeshiya Sabha area is one of the 19 local authorities in Gampaha District. It is located within $40 \mathrm{~km}$ North-East from Colombo, the primate city in Sri Lanka. The land area is $153.9 \mathrm{sqkm}$ in extent and amounts to $11 \%$ of the total land area of the Gampaha District. This area consists of 151 of Grama Niladhari Divisions (the last unit of the administrtaion syetm in Sri lanka) and 191 villages. There were 44,869 housing units in study area.

\subsection{Data and Data Collection}

Primary and secondary data sources were used to explore information for the research. Primary data was collected from the landowners who had already experienced the title registration program. They were interviewed using a structured questionnaire to collect the socio-economic and cultural factors (age, gender, education, monthly income, time of living in the land). Further, the questionnaire included questions to receive evaluative responses on views on Awareness and Participation, Trust and Trustworthiness, Access to information and attitudes and perception factors, of the participants were assessed on a five-point Likert scale, ranged from 1-5 representing: 1-strongly disagree, 2-disagree, 3- neutral, 4- agree, and 5- strongly agree.

Secondary data was collected from relevant and previously published research articles, reports, journals, etc. In addition, the secondary data was collected from the relevant institutes, mainly from the Ministry of Lands and Land Development, Department of Land Settlement and Attanagalla Divisional Secretariat.

\subsection{Population and Sample}

The population of the study included the residents of Attanagalla Pradeshiya Sabha area who have obtained a certificate through the title registration program. In this area, the title registration program has been implemented in 59 Grama Niladhari Divisions and altogether 39,120 people were considered as the population.

However, the study conducted focussing on six (06) Grama Niladhari Divisions in Attanagalla Pradeshiya Sabha area and 97 landowners were selected as the sample on a random basis.

\subsection{Conceptual Framework}

The conceptual framework of this study was developed to assess the influence of preidentified factors that graded the success of land title registration program. On theoretical grounds there are many factors affect on the acceptance of a project (Rubasinghe 2010), such as attitudes, awareness, access to information, legal and political issues, transparency etc. Subsequently, it can be argued that the acceptability of a project fosters the successfulness, and vice versa. However, this study focused on collecting the responses from the landowner's perspective and hence, only the factors that they were capable of answering had been selected. Table 1 shows the factors and the subfactors selected.

Table 1: Selected factors and the sub factors 


\begin{tabular}{|c|c|}
\hline Factors & \\
\hline Main-Factors & Sub Factors \\
\hline $\begin{array}{l}\text { Awareness and } \\
\text { Participation }\end{array}$ & $\begin{array}{l}\text { - Level of awareness } \\
\text { - Participation in the awareness programs } \\
\text { - } \text { Quality of the awareness program } \\
\text { - How they knew about the program }\end{array}$ \\
\hline $\begin{array}{l}\text { Trust and } \\
\text { Trustworthiness }\end{array}$ & $\begin{array}{l}\text { - Accuracy of the title certificate } \\
\text { - Accuracy of the field survey } \\
\text { - Systematic field investigation and surveying process in } \\
\text { accordance with the legal requirements } \\
\text { - Duration for issuing the title certificate }\end{array}$ \\
\hline $\begin{array}{l}\text { Land information } \\
\text { system }\end{array}$ & $\begin{array}{l}\text { - Data update } \\
\text { - Data sharing } \\
\text { - Access to public and publicity of information } \\
\text { - Receiving the cadastral map }\end{array}$ \\
\hline Attitudes & $\begin{array}{l}\text { - } \text { Preference for the project } \\
\text { - Idea about land conflicts } \\
\text { - Understanding of the steps of the title registration project. }\end{array}$ \\
\hline
\end{tabular}

Source: Compiled by Author, Survey Data 2019

\section{Data Analysis}

This study used quantitative data analysis methods. The collected primary data were analysed through the SPSS software for their reliability and the validity. The final analysis used descriptive statistics and one-sample t-test.

The majority i.e., $56 \%$ of the respondents in the sample were males. Most of the respondents i.e., $48 \%$ were within the age group of 40-59. The analysis shows that, $57 \%$ of the respondents were educated up to Advance Level examination (the secondary school). Hence, it can be concluded that they had adequate knowledge to respond to the questionnaire and they had responded to the study with adequate concisousness. Most participants i.e $65 \%$ employed in the private sector, and earned a monthly income in the range of LKR 20,000-39,000. Assuming that they did not have another sources of incone, it could be concluded that this majority belonged to the middle income earning group of the society.

Further, $38 \%$ had lived in the respective lands for more than 30 years. It reflected that most of the respondents had lived in the study area for a considerable period and therefore, had sufficient knowledge about Attanagalla area. The majority owned only one land parcel, which was more than 120 perches (approx.3000 square meters). It is understood that they had adequate land area for a resonable living in the area. In terms of use, the majority used the lands for residential purposes.

\subsection{Testing Reliability and Validity}

\subsubsection{Reliability Test}

Cronbach's Alpha was used to test all the independent variables and the dependent variables. It is the most common measurement of internal reliability. To measure the appropriateness of the measurement, the scale has been checked for its reliability using the reliability test. As it is commonly cited and accepted, the reliability scale should be equal to or above 0.7.The value of 0.7 means $70 \%$ of the variance in the scores is reliable variance and therefore, $30 \%$ is error variance. The following four independent variables were tested.

Table 2: Reliability test results

$$
\text { Reliability test results }
$$




\begin{tabular}{|l|l|}
\hline \multicolumn{1}{|c|}{$\begin{array}{c}\text { Independent } \\
\text { Variables }\end{array}$} & \multicolumn{1}{|c|}{ Cronbach's Alpha } \\
\hline $\begin{array}{l}\text { Awareness and } \\
\text { participation }\end{array}$ & .794 \\
\hline $\begin{array}{l}\text { Trust and } \\
\text { Trustworthiness }\end{array}$ & .908 \\
\hline $\begin{array}{l}\text { Access to } \\
\text { information }\end{array}$ & .850 \\
\hline $\begin{array}{l}\text { Attitudes and } \\
\text { Perception }\end{array}$ & .775 \\
\hline
\end{tabular}

Source: Compiled by Author, Survey Data 2019

As per Table 2, Cronbach's alpha value for all factors exceeded 0.7, which was a confirmation that the data was valid for further analysis.

\subsubsection{Validity Test}

In the validation process of the research survey instruments, two basic valids namely content and unidimensionarity were assessed to get the uniqueness of the measures.

All questions in the developed questionnaire were adopted from previous studies. By doing so, content validity was thus, ensured. Components for which the eigenvalue was less than 1.00 should be omitted from consideration because, these components account for less variance than a single variable contributes to the total variance. If the Eigenvalue is greater than 1.00 then the data support the assumption of unidimensionality (Brentani \& Golia, 2007). If Initial Eigenvalue is greater than 1 , it is better and high Initial Eigenvalue is better indicator, because it implies that those indicators all together explain the relevant variable.

A set of items is unidimentional if there exists a variable (often called a latent variable, as this variable may not be observed) which 'explains' all the correlations observed between the items. Formally stated, if the latent variable is maintained at a fixed level, then all the items are independent or uncorrelated, which is not absolutely equivalent but which is used in practice (Ziegler \& Hagemann, 2015) AVE should be greater than 0.5 . If all these requirements are fullfilled, variable is unidimentional.

Table 3: Validity Test Results

\begin{tabular}{|c|c|c|c|}
\hline Variables & $\begin{array}{l}\text { Initial } \\
\text { eigenval } \\
\text { ue }\end{array}$ & AVE & $\begin{array}{l}\text { factor } \\
\text { loading } \\
\text { values }\end{array}$ \\
\hline $\begin{array}{l}\text { Awareness } \\
\text { and } \\
\text { participation }\end{array}$ & 4.097 & $51.214 \%$ & $\begin{array}{l}.653 \\
.821 \\
.546 \\
.779 \\
.650 \\
.688 \\
.784 \\
.761\end{array}$ \\
\hline $\begin{array}{l}\text { Trust and } \\
\text { Trustworthi } \\
\text { ness }\end{array}$ & 4.934 & $61.670 \%$ & $\begin{array}{l}.805 \\
.810 \\
.730 \\
.832 \\
.782 \\
.690 \\
.832 \\
.791\end{array}$ \\
\hline $\begin{array}{l}\text { Access to } \\
\text { information }\end{array}$ & 4.403 & $62.896 \%$ & $\begin{array}{l}.859 \\
.914 \\
.871 \\
.844 \\
.704 \\
.647 \\
.666\end{array}$ \\
\hline $\begin{array}{l}\text { Attitudes } \\
\text { and } \\
\text { Perception }\end{array}$ & 3.551 & $71.028 \%$ & $\begin{array}{l}.807 \\
.857 \\
.900 \\
.796 \\
.849\end{array}$ \\
\hline
\end{tabular}

Source: Compiled by Author, Survey Data 2019

According to the above table, it is clear that variables are unidimentional since the Initial eigenvalues are greater than one. AVE and Component Matrix factor loading values are greater than $0.5(50 \%)$. It means that the responses complied with the theoritical propositions related to variables.

\subsubsection{Inferential Analysis}

\section{- Normality and Hypothesis Testing}

The normality test results indicate whether the data is normally distributed or not. In this study, a normality test was carried out for the four variables.

Reject H0, If "P value" < “ $\alpha$ value"

$\mathrm{P}=.000 \quad \alpha=.05$

$\mathbf{P}<\alpha$; HoRejected 
Table 4: Normality test results

\begin{tabular}{|l|l|l|}
\hline & $\begin{array}{l}\text { Kolmogorov } \\
\text {-Smirnov }\end{array}$ & $\begin{array}{c}\text { Shapiro } \\
\text {-Wilk }\end{array}$ \\
\hline $\begin{array}{l}\text { Awareness and } \\
\text { Participation }\end{array}$ & .055 & .256 \\
\hline $\begin{array}{l}\text { Trust and } \\
\text { Trustworthines } \\
\text { s }\end{array}$ & .059 & .042 \\
\hline $\begin{array}{l}\text { Access to } \\
\text { information }\end{array}$ & .058 & .088 \\
\hline Attitudes & .080 & .021 \\
\hline
\end{tabular}

Source: Compiled by Author, Survey Data 2019

Table 4 illustrates the results of the test of normality. There are two well-known tests of normality, namely the KolmogorovSmirnov Test and the Shapiro-Wilk Test. According to the Kolmogorov-Smirnov test, all the significant values of variables are above thealpha value of 0.05 . Therefore, these variables are normally distributed. Hence, the results allow theapplication ofthe parametric test. Therefore, "One sample t-test" was used for further analysis.

\section{- Application of One-Sample T-Test}

The acceptance level is the mean value of 4 that is taken for the test. According to the design of the Likert scale in the questionnaire, if the land owner's response was agree or strongly agree, the mean value should have been more than 4 . On the other hand, if the mean values were below the level 4, then it represented the respondents disagreed or strongly disagreed where the mid-point was used for neutrality. The justifications are based on the following.

A common and essential tool that has been applied in social science research in collecting responses is the Likert scale questionnaires generally ranging weights from $1-5$, representing strongly disagree to strongly agree level respectively (Subedi, 2016). A typical five-point response, the mid-point is considered as 3 and symbolizes, less than 3 as disagree and more than 3 being agree. In fact, the midpoints mostly represent 'neutral', 'undecided' or 'no idea' etc., where the respondents are neither agree nor disagree. Thus, it is the researcher's choice to decide the interpretation of results, concerning the epistemological concerns (Kulas et al 2008) at the designing level of the questionnaire.

Mohaidin et al, (2017) present the results based on the average value of 3 in fivepoint Likert scale responses, on the factors that affect in selecting tourism destination, where it discusses viz., if the values are more than 3 then the responses are favorable and if below 3 , then the responses are unfavorable on the factors. Following these scholarly discussions, since the midpoint of 3 symbolizes the 'neutral level' of this study, the decision rule was applied as, if the mean values were more than 4 , it was considered as the experience of the respondents on the specific criteria was favorable and promoted the successfulness while if the values were less than 4 , then the respondents' experiences were unfavorable of the criteria, hence demote the successfulness of the program.

\subsubsection{Hypotheses Testing}

\section{Factor 01:Awareness and Participation}

(The hypothesis is indicatred as mentioned below)

$\mathrm{H}_{0}: \mu \geq 4$

$\mathrm{H}_{1:} \mu<4$

According to One Sample t-test,

Sig value: 0.029

T value: -2.214

$\mathrm{T}$ value $<0$

So, $\mathrm{P}$ value $=\mathrm{Sig} / 2$

$$
\begin{aligned}
\alpha= & 0.05 \\
& =0.029 / 2 \\
& =\mathbf{0 . 0 1 4 5}
\end{aligned}
$$

$\mathrm{P}<\alpha$, therefore $\mathrm{H}_{0}$ is rejected.

Therefore, the mean value of responses of respondents isless than 4 .

\section{Factor 02:Trust and Trustworthiness}

$\mathrm{H}_{0}: \mu \geq 4$

$\mathrm{H}_{1:} \mu<4$

According to the One Sample t-test,

Sig value: 0.000

$T$ value: -3.625

$\mathrm{T}$ value $<0$

So, $\mathrm{P}$ value $=\operatorname{Sig} / 2$

$$
\alpha=0.05
$$




$$
\begin{aligned}
& =0.000 / 2 \\
& =\mathbf{0 . 0 0 0}
\end{aligned}
$$

$\mathrm{P}<\alpha$, therefore $\mathrm{H}_{0}$ is rejected.

So, mean value of responses of respondents are less than 4 .

\section{Factor 03:Access to Information}

$\mathrm{H}_{0}: \mu \geq 4$

$\mathrm{H}_{1:} \mu<4$

According to the One Sample t-test,

Sig value: 0.082

T value: -1.756

$\mathrm{T}$ value $<0$

So, $\mathrm{P}$ value $=\mathrm{Sig} / 2$

$$
\begin{aligned}
\alpha= & 0.05 \\
& =0.082 / 2 \\
& =\mathbf{0 . 0 4 1}
\end{aligned}
$$

$\mathrm{P}<\alpha$, therefore $\mathrm{H}_{0}$ is rejected.

Therefore, the mean value of responses of respondents isless than 4 .

\section{Factor 04:Attitudes and Perceptions}

$\mathrm{H}_{0}: \mu \geq 4$

$\mathrm{H}_{1:} \mu<4$

According to the One Sample t-test,

Sig value: 0.004

T value: 2.956

T value $>0$

$$
\begin{aligned}
& \text { So, } \mathrm{P} \text { value }=1-(\mathrm{Sig} / 2) \\
& \begin{aligned}
\alpha= & 0.05 \\
& =1-(0.004 / 2) \\
& =\mathbf{0 . 9 9 8}
\end{aligned}
\end{aligned}
$$

$\mathrm{P}>\alpha$, therefore $\mathrm{H}_{0}$ is accepted.

Therefore, the mean value of responses of respondents is more than 4. Table 5 presetns the results on the average mean values of the responses in each factor.

Table 5: Average mean values of the factors

\begin{tabular}{|l|l|l|}
\hline & Factor & Mean \\
\hline 1 & Awareness and participation & 3.91 \\
\hline 2 & Trust and trustworthiness & 3.78 \\
\hline 3 & Access to information & 3.90 \\
\hline 4 & Attitudes & 4.15 \\
\hline
\end{tabular}

Source: Compiled by the Author, Survey Data 2019

According to this table, all the mean values are below the average value of 4 except the attitude factor. The mean value for the attitude factor is above 4 and shows that there is a favorable response for the attitudes factor.

- Mean values of Awareness and Participation

Table 6: Mean values of Awareness and Participation

\begin{tabular}{|l|l|l|}
\hline & \multicolumn{1}{|c|}{ Statements } & Mean \\
\hline 1 & $\begin{array}{l}\text { Got to know about title } \\
\text { registration program } \\
\text { through awareness } \\
\text { program }\end{array}$ & 3.69 \\
\hline 2 & $\begin{array}{l}\text { Participation inthe } \\
\text { awareness program }\end{array}$ & 3.31 \\
\hline 3 & $\begin{array}{l}\text { The convenienceof time } \\
\text { and location of the } \\
\text { awareness program }\end{array}$ & 3.63 \\
\hline 4 & $\begin{array}{l}\text { Acknowledged about } \\
\text { thetitle registration } \\
\text { program before } \\
\text { participating in the } \\
\text { awareness program }\end{array}$ & 3.61 \\
\hline 5 & $\begin{array}{l}\text { Got to know about the title } \\
\text { registration program } \\
\text { through GramaNiladhari }\end{array}$ & 4.38 \\
\hline 6 & $\begin{array}{l}\text { Got to know about the title } \\
\text { registration program } \\
\text { through neighbours }\end{array}$ & 4.22 \\
\hline 7 & $\begin{array}{l}\text { Got to know about the title } \\
\text { registration program } \\
\text { through project officers }\end{array}$ & 4.24 \\
\hline 8 & $\begin{array}{l}\text { Getting a clear idea about } \\
\text { the awareness program }\end{array}$ & 4.18 \\
\hline Source: Compiled by Author, Survey Data 2019 \\
\hline
\end{tabular}

Table 6 indicates the average responses of the participants regarding the awareness and participation factor. According to this table, the mean value is above 3 for all the statements. This indicates people's well awareness about the title registration program in different ways. According to the majority of respondents, they had got to know about the title registration program through Grama Niladhari. Similarly, they have got to know about the awareness program through project officers and neighbors. At the same time, the least number of respondents participated in the awareness program conducted by the BimSaviya project. 
- The Mean values of trust and trustworthiness

Table 7: Mean values of trust and trustworthiness

\begin{tabular}{|l|l|l|}
\hline & Statements & Mean \\
\hline 1 & $\begin{array}{l}\text { Systematic field } \\
\text { investigation and } \\
\text { surveying process. }\end{array}$ & 4.16 \\
\hline 2 & $\begin{array}{l}\text { Accuracy of the field } \\
\text { survey }\end{array}$ & 4.33 \\
\hline 3 & $\begin{array}{l}\text { Duration for issuing title } \\
\text { certificate }\end{array}$ & 3.16 \\
\hline 4 & $\begin{array}{l}\text { Accuracy of the title } \\
\text { certificate }\end{array}$ & 4.04 \\
\hline 5 & $\begin{array}{l}\text { Access to get bank credit } \\
\text { and loans after the } \\
\text { registration }\end{array}$ & 4.02 \\
\hline 6 & $\begin{array}{l}\text { Durationfor the process of } \\
\text { the title registration } \\
\text { program }\end{array}$ & 2.91 \\
\hline 7 & $\begin{array}{l}\text { Connection with the } \\
\text { Bimsaviya office }\end{array}$ & 3.86 \\
\hline 8 & $\begin{array}{l}\text { Land value after getting } \\
\text { the certificate }\end{array}$ & 3.77 \\
\hline
\end{tabular}

Source: Compiled by the Author, Survey Data 2019

Table7 illustrates the average responses of respondents regarding the trust and trustworthiness of the title registration program. The majority of the respondents had trustworthiness about the accuracy of the field survey. Similarly, they had maintained trustworthiness about the field investigation and surveying process, the accuracy of the title certificate as well as access to bank credits. At the same time, the mean value of the time for the process of title registration program was 2.91 and it was the least mean value relative to other responses.

- Mean values of access to information

Table 8: Mean values of access to information

\begin{tabular}{|l|l|l|}
\hline 1 & Statements & Mean \\
\hline 1 & $\begin{array}{l}\text { Receiving the booklet of } \\
\text { title registration }\end{array}$ & 3.71 \\
\hline 2 & $\begin{array}{l}\text { Adequate information of } \\
\text { the booklet }\end{array}$ & 3.97 \\
\hline
\end{tabular}

\begin{tabular}{|c|l|l|}
\hline 3 & $\begin{array}{l}\text { Clearness, understandable, } \\
\text { accuracy, and truthful of } \\
\text { information of booklet }\end{array}$ & 3.92 \\
\hline 4 & $\begin{array}{l}\text { Sources of getting } \\
\text { information }\end{array}$ & 4.07 \\
\hline 5 & $\begin{array}{l}\text { Access to get information } \\
\text { about the cadastral map }\end{array}$ & 3.79 \\
\hline 6 & $\begin{array}{l}\text { Access to get information } \\
\text { through the internet }\end{array}$ & 3.66 \\
\hline 7 & $\begin{array}{l}\text { Support from Land } \\
\text { Settlement Department }\end{array}$ & 4.19 \\
\hline
\end{tabular}

Source: Compiled by Author, Survey Data 2019

Table 8 presents the average responses of the respondents regarding access to information. According to this table, there were different responses, and the mean value was above 3 for all statements. This is an indication that people get information in indifferent ways. The majority of the respondents got information through the Land Settlement Department. According to this table, least responses were for accessing information from the internet.

- Mean values of attitudes and perceptions

Table 9: Mean values of attitudes and perceptions

\begin{tabular}{|l|l|l|}
\hline & Statements & Mean \\
\hline 1 & $\begin{array}{l}\text { Preference to the title } \\
\text { registration }\end{array}$ & 4.37 \\
\hline 2 & $\begin{array}{l}\text { Understanding of steps of } \\
\text { the title registration } \\
\text { program }\end{array}$ & 3.82 \\
\hline 3 & $\begin{array}{l}\text { Security to landowners } \\
\text { from title registration }\end{array}$ & 4.11 \\
\hline 4 & $\begin{array}{l}\text { Minimizing the land } \\
\text { conflicts }\end{array}$ & 4.11 \\
\hline 5 & $\begin{array}{l}\text { Benefits of title } \\
\text { registration }\end{array}$ & 4.31 \\
\hline
\end{tabular}

Source:Compiled by the Author, Survey Data 2019

Table 9 presents the average responses of the respondents regarding the attitudes of the title registration program. According to this table, all responses were positive, and the mean value was above 3 for all the statements. It means the respondents had positive attitudes towards the title registration program. According to this table, the least responses were observed concerning the understanding of steps of the title registration program. 


\section{Conclusion and Recommendations}

This study intends to examine the perceptios of landowers's towards the success of land title registration program in Sri Lanka. The success of the overall land title registration varied on certain factors such as awareness and participation, trust and trustworthiness, land information system, and attitudes. Based on a comprehensive literature study 15 variables were derived under four headings. .

The results revealed that the attitude factor had a high mean value, implying that it contributed to higher responsiveness for the land title registration program. Further, it promoted the success of the program. The factors such as trust and trustworthiness, participation in the awareness program, access to information had relatively lower mean values implying lower responses because the respondents had less knowledge on the benefits of the program and did not trust the system. Thus, these factors contribute to demote the success of the title registration program. Therefore, it can be concluded that out of the four factors that were tested, three factors influenced to degrade the success of the title registration program in Sri Lanka.

Based on the findings of the study, it can be recommended that to overcome the above issues, the Land Settlement Department may have to conduct continuous awareness programs about the title registration system. Also, people should be induced in such programs. Participation in the awareness programs was very low. Therefore, effective methods need to be used to enhance the awarenes among public through mass media, Grama Niladhari, or through leaflets and newspaper articles, etc.

In addition, it is crucial to accelerate the ongoing process with the participation of more human resources while opening more access to inforamtion. Meetings may be arranged parallel to other programs and at the village level. Similarly, the title certificate need to be issued on time and effectively. Therefore, responsible authorities must consider the above findings to promote the program. Thus, the policies should be formulated to minimize the demoting factors of the title registration program by accelerating the awareness program to increase the knowledge and trustworthiness among people on the title registration process in Sri Lanka.

\section{Acknowledgment}

The authors wish to acknowledge the Centre for Real Estate Studies (CRES), Department of Estate Management and Valuation, University of Sri Jayewardenepura, Sri Lanka.

\section{References}

AusAID, (2001). Undertaking land administration projects: Sustainability, affordability, operational efficiency, and good practice guidelines. performance information and assessment section, The Australian Government's Overseas Aid Program, AusAID, Canberra.

Ayala, G. X., \& Elder, J. P. (2021, August 03). Qualitative methods to ensure acceptability of behavioral and social interventions to the target population. Retrieved from National Libruary of Medicine: https://pubmed.ncbi.nlm.nih.gov/21656958/

BimSaviya, (2009).Webpage of BimSaviya. Ministry of Land and Land Development, Government of Sri Lanka, Available at http://bimsaviya.landmin.gov.lk/[last accessed 29/06/2021]

Brentani, E., \&Golia, S. (2007). Unidimensionality in the Rasch model: how to detect and interpret. Statistica, 67(3), 253-261.

Bucero, A. (2010). Why is attitude important for project success? Paper presented at PMI® Global Congress 2010 - EMEA, Milan, Italy. Newtown Square, PA: Project Management Institute.Burns, T., Grant, C., Nettle, 
K., Brits, A. M., \& Dalrymple, K. (2006). Land administration reform: indicators of success and future challenges. In Agriculture and Rural Development Discussion Paper-World Bank, Pennsylvania.

Dale, P., \&Binns, B. (1995). Cadastral surveys and records of right, Food and Agriculture Organization of the United Nations, Rome

Dale P F.,\& McLaughlin J D (1999). Land Administration. Clarendon press, Oxford, pp 1-25.

Dale, P. F., \& McLaughlin, J. D. (1988). Land information management: An introduction with special reference to cadastral problems in third world countries, Oxford Clarendon Press, United Kingdom.

David L. Mclain and Hackman, K., 1999. Trust, Risk and Decision-Making in Organizational Change. Public Administration Quarterly: 152-176.

De Soto Hernando De (1989) The other path: The invisible resolution in the third world. Herper and Row. New York.

Enemark, S., 2008. Underpinning Land Management - A Major Challenge for the Global Surveying Profession, International Congress on Geomatics and Surveying Engineering and Top-cart, Valencia, Spain.

Ehwi, R. J., \& Asante, L. A. (2016). Ex-post analysis of land title registration in Ghana since 2008 merger: Accra lands commission in perspective. Sage Open, 6(2), 2158244016643351. https://doi.org/10.1177/2158244016643351

Griffith-Charles, C. (2004). The impact of land titling on land transaction activity and registration system sustainability: A case study of St. Lucia. University of Florida.

Henssen, J. (1995). Basic principles of the main cadastral systems in the world. In the Proceedings of the oneday seminar held during the Annual Meeting of Commission. Australia.

Heryani, E. \& Grant, C., (2004). Land administration in Indonesia. In the Proceedings of 3rd International Federation of Surveyors Regional Conference, Jakarta.

Illanganthilaka, N., \&Mahanamahewa, P. (2016). Registration System in Sri Lanka: Comparative Study of Law in Austria and Ghana, In the Proceedings in law, 9th International Research Conference-KDU, Sri Lanka.

Jones, D. S. (2010). Land registration and administrative reform in Southeast Asian States: Progress and constraints. International Public Management Review, 11(1), 67-89

Kidokoro, T., Perera, U., \&Onishi T. (2007). Land tenure and development policies: It's impact on land market: The case of Colombo Sri Lanka.

Kulas, J. T., Stachowski, A. A., \& Haynes, B. A. (2008). Middle response functioning in Likert-responses to personality items. Journal of Business and Psychology, 22(3), 251-259. doi: 10.1007/s10869-008-90642.Lengoiboni, M., Richter, C., \& Zevenbergen, J. (2018). An overview of initiatives to innovate land tenure recordation: 2011 to present. In the Proceedings of the World Bank Conference on Land and Poverty, Washington, (pp. 19-23).

Lengoiboni, M., Richter, C., \& Zevenbergen, J. (2019). Cross-cutting challenges to innovation in land tenure documentation. Land use policy, 85, 21-32.https://doi.org/10.1016/j.landusepol.2019.03.023.

Lor, D., (2004). Community participation supporting cost effective surveying methods, In the Proceedings of 3rd FIG Regional Conference, Jakarta, Indonesia.

Mitchell, D., Clarke, M. and Baxter, J., (2008). Evaluating land administration projects in developing countries. Land Use Policy, 25(4), 464-473.https://doi.org/10.1016/i.landusepol.2007.10.004.

Mohaidin, Z., Wei, K. T., \& Ali Murshid, M. (2017). Factors influencing the tourists' intention to select sustainable tourism destination: a case study of Penang, Malaysia. International Journal of Tourism Cities, 3(4), 442-465. https://doi.org/10.1108/ijtc-11-2016-0049 
Nichols, S. E. (1993). Land registration: managing information for land administration. Department of Surveying Engineering, University of New Brunswick.

Pieris G.H., (1989). Peasant agriculture and irrigated agriculture in the dry zone of Sri Lanka, Ethnic Studies Report, Vol.VII, No.2,

Perera, T. G. U. P. (2010). Implementing land registration systems in Sri Lanka: being pragmatic. Journal of Sri Lankan Real Estate, 74-96.

Rubasinghe, R. (2010). Evaluating acceptability of land titling: a case study in Sri Lanka. University of Twente, Netherlands.

Roth, M. and D. Haase (1998). Land Tenure Security and Agricultural Performance in Southern Africa.

Rydbberg, Kaddik, L. J., \&Jona. (2013). The Subdivision and Amalgamation Procedure in Sri Lanka. Sweden.

Simpson, S.R., (1976). Land law and registration. Cambridge University Press, Cambridge.

Subedi B P (2016) Using Likert Type Data in Social Science Research: Confusion, Issues and Challenges International Journal of Contemporary Applied Sciences Vol. 3, No. 2, 36-49.

Thontteh, E. O., \&Omirin, M. M. (2015). Land registration within the framework of land administration reform in Lagos state. Pacific Rim Property Research Journal, 21(2), 161-177.

Tuladhar, A.M. and van der Molen, P., (2003). Customer Satisfaction Model and Organizational Strategies for Land Registration and Cadastral Systems, 2 nd Cadastral Congress, Krakow.

UN-Habitat (2007). How to develop a pro-poor land policy? Process, guide and lessons, United Nations Human Settlement Programme (UN-Habitat), Kenya.

World Bank, (2001). Document of World bank: Project Appraisal Document on a proposed Credit in the amount of SDR 3.9 million to the Democratic Socialist Republic of Sri Lanka for the Land Titling Related Services Project.

Zainudeen, M. H. (2016). Land administration in Sri Lanka: Issues and challenges. In the Proceedings of World Bank Conference on Land and Poverty, The World Bank, Washington.

Zevenbergen, J., (2002a). A system approach to land registration and cadastre, In the Proceedings of FIG XXII International Congress, Washington, D.C. USA.

Zevenbergen, J., (2002b). Systems of land registration aspects and effects. Netherlands Geodetic Commission Publications on Geodesy.

Zevenbergen, J.A., (2004). A systems approach to land registration and cadastre. Nordic Journal of Surveying and Real Estate Research, 1.

Zevenbergen, J.A., (2006). Slowly towards trustworthy land records of pre-exiting land rights, In the Proceedings of FIG xxiii International Congress, Munich, Germany.

Ziegler, M., \&Hagemann, D. (2015). Testing the Unidimensionality of items. European Journal of Psychological Assessment. Retrieved from https://www.researchgate.net/publication. 